\title{
OPTIMASI RUTE DISTRIBUSI PRODUK NESTLE MENGGUNAKAN METODE BRANCH AND BOUND DAN TWO-WAY EXCHANGE IMPROVEMENT HEURISTIC (STUDI KASUS : PT. PARIS JAYA MANDIRI - AMBON)
}

\author{
Daniel B. Paillin ${ }^{* 1)}$, Johan M Tupan ${ }^{1)}$ \\ Email: dani_ti_fatek@yahoo.co.id,johan.tupan@fatek.unpatti.ac.id \\ ${ }^{1)}$ Jurusan, Teknik Industri, Universitas Pattimura, Kampus Poka, Ambon, 97233, Indonesia
}

\begin{abstract}
ABSTRAK
Traveling Salesman Problem (TSP) merupakan permasalahan optimasi pencarian rute terpendek dari satu kota ke nkota lain tepat satu kali dan akan kembali ke titik awal keberangkatan. TSP dikategorikan sebagai hard combinatorial problem sehingga banyak teknik maupun aproksimasi yang dikembangkan untuk pemecahannya. Penelitian ini bertujuan untuk membandingkan teknik branch and bound dengan two-way exchange improvement dalam pemecahan Traveling Salesmen Problem (TSP) didasarkan pada jarak tempuh terkecil dan total waktu tempuh terkecil kendaraan. Penelitian ini diaplikasikan pada kasus nyata permasalahan penentuan rute kendaraan untuk pengiriman produk nestle dari PT. Paris Jaya Mandiri di kota Ambon. Hasil penelitian menunjukan bahwa teknik Two-Way Exchange Improvement memberikan hasil terbaik dibandingkan dengan Branch and Bound, dengan persentase penghematan jarak sebesar $18.09 \%$ dan penghematan total waktu sebesar $7.99 \%$ dari rute regular perusahaan.
\end{abstract}

Kata kunci:, branch and bound, two-way exchange improvement, rute kendaraan, traveling salesman problem

\section{PENDAHULUAN}

Salah satu perusahaan agen distributor produk Nestle di kota Ambon adalah PT. Paris Jaya dengan daerah pendistribusian meliputi wilaya Ambon dan Masohi. Untuk wilayah distribusi kota Ambon sendiri meliputi kecamatan Sirimau dan kecamatan Nusaniwe dengan jumlah outlet sebanayak 67 yang tersebar pada 39 titik lokasi yang berbeda. Saat ini PT. Paris Jaya belum memiliki rute yang pasti dalam pendistribusian produk yang menyebabkan pertambahan jarak dan watu tempuh sehingga berdampak pada tingginya biaya tranportasi dan terjadinya keterlambatan pengiriman produk ke konsumen. Untuk itu, perlu dilakukan penentuan rute optimal sehingga perusahaan dapat melakukan aktivitas distribusi secara efektif dan efisien, permasalahan penentuan rute ini lebih dikenal dengan Traveling Salesman Problem (TSP).

TSP merupakan salah satu permasalahan optimasi kombinatorial (hard combinatorial problem) yang biasa terjadi, yang mana seseorang harus mengunjungi semua kota tepat satu kali dan kembali ke kota asal (Lawler et.al, 1983). Telah banyak pendekatan atau algoritma yang digunakan baik teknik optimal maupun pendekatan heuristic seperti branch and bound, cheapest insertion, simulated annealing, ant colony, dan lain-lain. Paillin dan Sosebeko, 2017, menggunakan teknik branch and bound untuk pemecahan TSP pada PT. Paris Jaya Mandiri dengan cara mengklasterisasi konsumen berdasarkan kedekatan wilayah. Hillier and Lieberman, 2001, mengatakan bahwa Konsep utama dari metode Branch and Bound adalah membagi masalah aslinya yang berukuran besar menjadi sub masalah yang lebih kecil kemudian menjadi anak gugus yang lebih kecil lagi sampai semua submasalah dapat diselesaikan. Fatmawati, et.al, 2015 menyelesaikan TSP menggunakan algoritma tabu search dengan meminimumkan jarak tempuh dan waktu perjalanan sehingga memperoleh rute optimal, algoritma ini berbasis pada pencarian local dengan cara bergerak dari satu solusi ke solusi berikutnya dan memilih solusi terbaik dan bertujuan untuk mencegah proses pencarian ulang pada ruang solusi yang pernah ditelusuri (Suyanto, 2010). Paillin dan Tupan, 2018, juga menyelesaikan TSP untuk menentukan rute optimum dengan cara membandingkan performansi solusi dari algoritma branch and bound dan cheapest insertion. Banyak teknik dan algoritma yang dapat digunakan untuk menyelesaikan masalah TSP. Masing-masing algoritma memiliki kelebihan dan kekurangannya. Suatu algoritma memiliki hasil yang berbedabeda, karena belum tentu suatu algoritma yang memiliki optimasi yang tinggi untuk suatu kasus 
memiliki optimasi yang tinggi pula untuk kasus yang lain. (Paillin dan Tupan, 2018).

Berdasarkan permasalahan diatas, penulis tertarik untuk membahas penentuan rute distribusi produk yang optimal yang harus dilalui, sehingga penyaluran produk dapat menjadi lebih efisien.

\section{KAJIAN TEORI DAN METODE}

\section{Traveling Salesman Problem}

TSP merupakan salah satu permasalahan optimasi kombinatorial. Permasalahan matematika tentang TSP dikemukan pada tahun 1800 oleh matematikawan Irlandia, Willian Rowan Hamilton dan matematikawan Inggris Thomas Penyngton. TSP merupakan sekumpulan kota dan biaya perjalanan (atau jarak) yang diberikan antar masing-masing pasangan kota yang digunakan untuk menemukan jalan terbaik kunjungan ke semua kota dan kembali ke titik awal dalam upaya meminimalkan biaya atau jarak perjalanan (Devendra. D, 2010)

Formulasi model penentuan rute TSP dapat ditulis sebagai berikut: Jarak perjalanan dari titik i ke titik j direpresentasikan oleh $C_{i j}$. Selanjutnya didefinisikan variabel keputusan $X_{i j}$ yang merepresentasikan ada tidaknya perjalanan dari titik $i$ ke $j$ dalam suatu rute sebagai berikut :

$X_{i j}=\left\{\begin{array}{l}1, \mathrm{Jika} \text { terdapat perjalanan kendaraan dari i ke } \mathrm{j} \\ 0, \text { Jika tidak ada perjalanan kendaraan dari i ke } \mathrm{j}\end{array}\right.$

Jika Z merupakan fungsi tujuan TSP, maka fungsi tujuan $\mathrm{Z}$ dirumuskan dengan meminimumkan

$$
Z=\sum_{i=1}^{n} \sum_{j=1}^{n} C_{i j} X_{i j}
$$

dengan batasan kendala,

$$
\begin{array}{ll}
\sum_{i=1}^{n} X_{i j}=1 & (i=1,2,3, \ldots . N) \\
\sum_{j=1}^{n} X_{i j}=1 \quad(i=1,2,3, \ldots . N) \\
X_{i j}=0 \text { atau } 1
\end{array}
$$

Batasan yang pertama dan kedua memastikan bahwa rute yang terpilih mendatangi setiap kota 1 kali dan meninggalkan kota tersebut 1 kali.

\section{Algoritma Branch And Bound}

Branch and bound merupakan merupakan metode algoritma yang umum digunakan untuk menentukan penyelesaian optimal dari masalah optimisasi, khususnya pada diskrit dan optimisasi kombinatorial. Pada intinya algoritma ini menggunakan pendekatan enumerasi dengan cara mematikan search space yang tidak mengarah pada penyelesaian. Pada tahun 1960, algoritma branch and bound diperkenalkan oleh A.H. Land dan A.G. Doig.

Sesuai dengan namanya branch and bound memiliki dua alat yaitu branching dan bounding. Branching dilakukan dengan cara meng-cover daerah penyelesaian yang layak dengan beberapa sub daerah layak yang lebih kecil. Bounding dilakukan dengan cara menentukan nilai batas atas dan batas bawah untuk penyelesaian optimal di dalam sub daerah yang layak.

Proses branching menggunakan skema Breadth First Search (BFS). Simpul atau titik yang dibangkitkan terlebih dahulu merupakan simpul yang bertetangga dengan simpul akar. Namun proses pemilihan simpul yang akan diperluas (simpul expand) tidak seperti pada $B F S$ murni. Tidak seperti $B F S$ murni yang memilih simpul expand berdasarkan urutan pembangkitan, pada algoritma branch and bound pemilihan simpul expand didasarkan pada nilai fungsi objektif.

Masalah optimisasi biasanya memiliki fungsi untuk menghasilkan nilai batas yang unik. Sedangkan pada algoritma branch and bound pemilihan formula fungsi menggunakan metode heuristic, berdasarkan pada pengalaman dan instinc pembuat program dan tidak ada bukti matematisnya. Hasil optimisasi yang diperoleh melalui algoritma ini bergantung pada keakuratan pemilihan fungsi batas tersebut. Tidak ada cara baku untuk menentukan fungsi batas karena masalah yang sama bisa saja memiliki rumus perhitungan nilai batas yang berbeda.

Langkah-langkah algoritma branch and bound untuk menyelesaikan TSP adalah sebagai berikut.

Langkah 1:

Tetapkan penyelesaian awal masalah. Penyelesaian yang ditetapkan merupakan rute perjalanan lengkap. Tentukan batas tertinggi pada nilai minimum fungsi objektif dengan mencari 
berbagai kemungkinan rute perjalanan. Batas atas ini dinotasikan dengan $f_{u}$.

\section{Langkah 2:}

Buat cabang awal dengan mengatur $x_{1}=1$ untuk masing-masing kota $j=2,3, \ldots, n$. Untuk $i=j$, nilai $C_{i j}=M$ untuk menyatakan rute yang tidak mungkin. Hitung batas terendah yang dinotasikan dengan $f_{L}$ pada nilai minimum fungsi objektif di setiap titik. Dari data awal, hapus baris pertama dan kolom ke $j$, serta ganti $C_{i j}=M$. Tentukan penyelesaian masalah dan tambahkan harga $f$ ke $C_{i j}$ untuk memperoleh $f_{L}$ sehingga $f_{L}=C_{i j}+f$. Jika $f_{L} \leq f_{U}$ aktifkan simpul, dan jika sebaliknya hapus simpul.

\section{Langkah 3:}

Jika tidak ada simpul aktif pada langkah ini maka penyelesaian terbaik saat ini adalah optimal. Jika tidak, pilih simpul dengan nilai $f_{L}$ terkecil dan buat cabang baru dengan mengatur $x_{j k}=1$ untuk setiap kota yang belum dikunjungi sebelumnya.

Langkah 4.

Buat batasan $f$ pada setiap simpul dengan menghapus baris $j$ dan kolom $k$ dari data pada simpul aktif diatasnya. Tambahkan nilai $f$ ke $C_{j k}$ dengan seluruh nilai sebelumnya.

\section{Algoritma Two-Way Exchange Improvement Heuristic}

Christata (2014) dan Chang (2003) menyebutkan two-way exchange improvement merupakan heuristic improvement khusus untuk menyelesaikan TSP. Metode ini diartikan sebagai asumsi $(I, j)$ dan $(k, l)$ merupakan dua titik yang berdekan pada suatu kunjungan. Menghilangkan dua titik yang tidak saling berdekatan dari suatu kunjungan akan membuat dua potongan, misalnya A dan B. Menghubungkan kembali kunjungan lengkap dengan salah satu dari $(i)$ menggantikan A serta menghubungkan $(I, j)$ dan $(j, k)$ atau (ii) menggantikan B dan menghubungkan $(I, k)$ dan $(j, l)$. Langkahnya adalah sebagai berikut :

a. Mengunakan inisialisasi kunjungan dari metode nearest neighbor atau cheapest insertion.

b. Memeriksa semua kemungkinan penggantian dua arah untuk kunjungan sekarang dan memilih yang terbaik sebagai perbaikan. Jika tidak didapatkanperbaikan maka hentikan langkah ini.

c. Lakukan penggantian dua arah untuk membentuk kunjungan baru, kembali ke langkah $\mathrm{b}$.
Berikut ini adalah tahapan penelitian yang dilakukan dapat dilihat pada gambar 2 . berikut ini

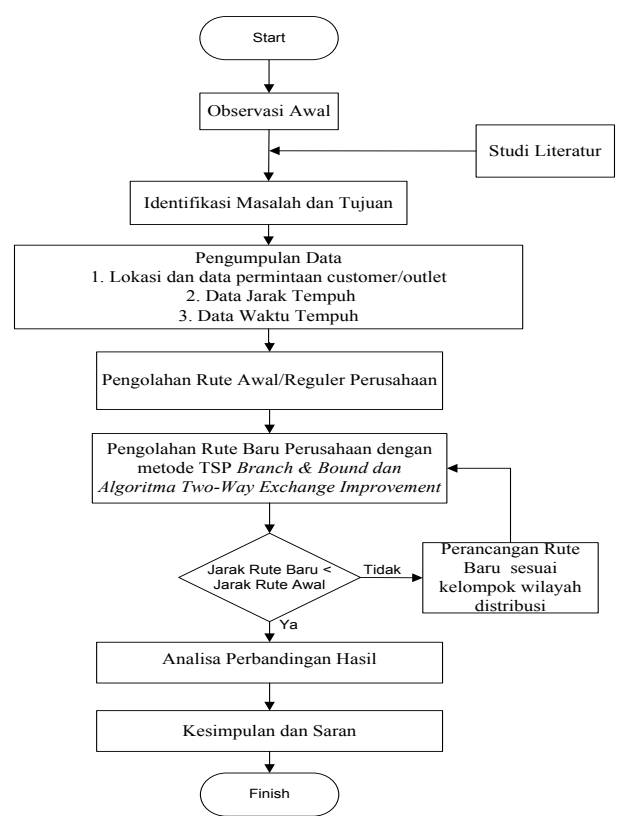

Gambar 1. Flowchart Penelitian

HASIL DAN PEMBAHASAN

Deskripsi Sistem Pendistribusian Produk

Nestle di Kota Ambon

Kegiatan distribusi produk Nestle yang dilakukan oleh PT. Paris Jaya Mandiri mencakup 2 wilayah yang ada di Kepulauan Ambon yaitu wilayah kecamatan Sirimau dan kecamatan Nusaniwe. Cakupan wilayah kecamatan Sirimau dimulai dari Galala - Air Mata Cina dan cakupan wilayah kecamatan Nusaniwe dimulai dari Waihaong - Seri. Berikut merupakan gambaran wilayah distribusi produk Nestle di pulau Ambon.

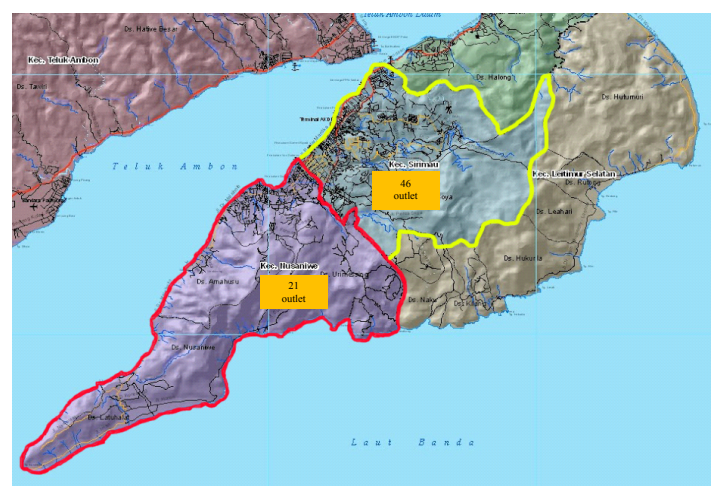

Gambar 2. Peta Umum Sebaran Outlet di Pulau Ambon

\section{Data Lokasi dan Permintaan Outlet}

Berikut merupakan daftar lokasi dari kode customer (KC) dan demand (D) dari outlet yang 
akan dikunjungi.KC (PJM) PT. Paris Jaya Mandiri

Tabel 1. Lokasi dan Jumlah Permintaan Outlet PT. Paris Jaya Mandiri Ambon

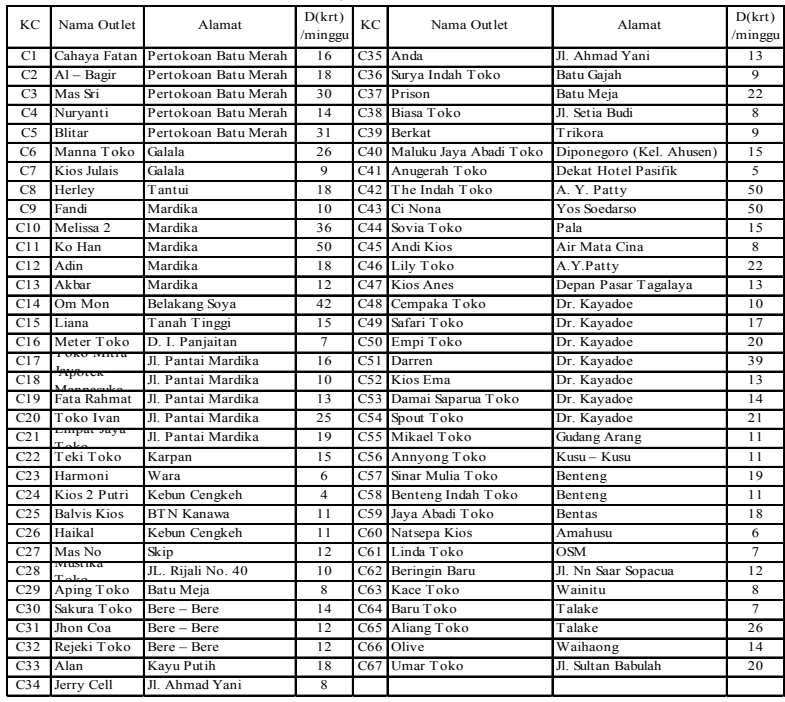

\section{Data Jarak Tempuh}

Data jarak tempuh adalah data jarak dari depot PT. Paris Jaya Mandiri menuju sejumlah oulet yang dituju dan juga jarak antaroutlet. Perhitungan jarak diperoleh dengan rumus Euclidean $\quad d_{(i j)}=\sqrt{(x i-x j)^{2}+(y i-y j)^{2}}$ dengan titik $\mathrm{x}$ dan $\mathrm{y}$ merupakan titik latitude dan longitude outlet yang diperoleh melalui google maps.

Tabel 2. Matriks Jarak Antar outlet Wilayah Sirimau 1

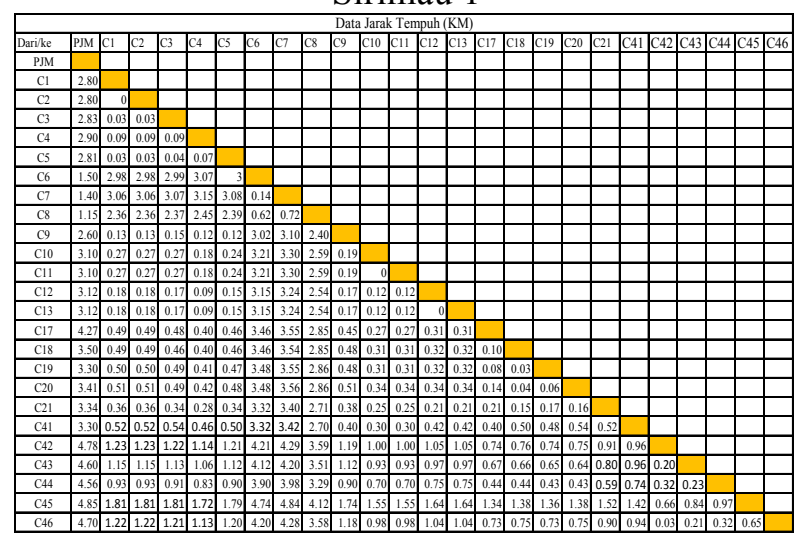

Tabel 3. Matriks Jarak Antaroutlet Wilayah Sirimau 2

\begin{tabular}{|c|c|c|c|c|c|c|c|c|c|c|c|c|c|c|c|c|c|c|c|c|c|c|c|}
\hline \multicolumn{24}{|c|}{ Data Jarak Tempuh (KM) } \\
\hline & PJM & & C15 & C16 & $\mid c 22$ & & $\mathrm{C} 24$ & C25 & & & & & & & & $\mathrm{C} 32 \mathrm{C}$ & C33 & $\begin{array}{ccc}34 & C 35 \\
\end{array}$ & $35 \quad 36$ & & $\begin{array}{lll}c 38 & c \\
\end{array}$ & $\begin{array}{ccc}c & c \\
c\end{array}$ & \\
\hline PJM & & & & & & & & & & & & & & & & & & & & & & & \\
\hline $\mathrm{Cl} 4$ & 2.70 & & & & & & & & & & & & & & & & & & & & & & \\
\hline $\mathrm{C15}$ & 3.40 & 0.59 & & & & & & & & & & & & & & & & & & & & & \\
\hline $\mathrm{C} 16$ & 4.00 & 0.45 & 0.5 & & & & & & & & & & & & & & & & & & & & \\
\hline $\mathrm{C} 22$ & 4.50 & 0.19 & & 0.57 & & & & & & & & & & & & & & & & & & & \\
\hline $\mathrm{C} 23$ & 3.60 & 3.3. & 3.7 & & 3.2 & & & & & & & & & & & & & & & & & & \\
\hline $\mathrm{C} 24$ & 1.60 & $1.76 \mathrm{r}$ & 2.2 & 2.20 & 1.6 & 1. & & & & & & & & & & & & & & & & & \\
\hline $\mathrm{C25}$ & & 2.79 & 3.2 & & 2.6 & & 1.0 & & & & & & & & & & & & & & & & \\
\hline $\mathrm{C26}$ & 2.30 & 2.4 & 2.8 & 2.88 & 2.3 & 0. & 0.7 & 0 & & & & & & & & & & & & & & & \\
\hline $\mathrm{C} 27$ & 3.70 & 0.69 & 0.1 & 0.66 & 0.8 & 3. & 2.2 & 3. & 2.8 & & & & & & & & & & & & & & \\
\hline C28 & 3.50 & 0.69 & 0.1 & 0.62 & 0.8 & 3. & 2. & 3. & 2.9 & 20. & & & & & & & & & & & & & \\
\hline C29 & 4.10 & 0.81 & 0.2 & 0.65 & & 3.5 & 52.4 & 3. & 3.6 & 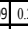 & 230 & & & & & & & & & & & & \\
\hline $\mathrm{C} 30$ & 3.89 & 0.9 & 0.3 & 0.79 & 1.0 & 3.4 & 5. & 3. & 3 & 10 & 240 & & 0.14 & & & & & & & & & & \\
\hline $\begin{array}{l}31 \\
\end{array}$ & 3.98 & & 0.4 & 0.94 & 1.1 & 3.9 & 3.5 & 3. & 3.0 & $\begin{array}{ll}9 & 0 . \\
\end{array}$ & $\begin{array}{l}2 \\
2\end{array}$ & & 0.31 & 0.17 & & & & & & & & & \\
\hline $\mathrm{C} 32_{2}$ & 4.02 & 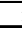 & 0.4 & 0.94 & 1.1 & 3. & 32.5 & 13. & 3.0 & $\begin{array}{ll}90 . & 0 .\end{array}$ & 320 & & 0.31 & 0.17 & 0.00 & & & & & & & & \\
\hline C33 & 4.40 & 0.99 & 0.4 & 0.86 & 1.1 & \begin{tabular}{|l|l}
4. \\
\end{tabular} & 2.5 & \begin{tabular}{l|l}
73. \\
\end{tabular} & 3.1 & $\begin{array}{ll}77 & 0 \\
\end{array}$ & & & & 0.08 & & 0.14 & & & & & & & \\
\hline C34 & 3.71 & 0.9 & 0.4 & \begin{tabular}{|l|l|}
0.82 \\
\end{tabular} & 1.1 & \begin{tabular}{|l|l}
4. \\
\end{tabular} & 2.6 & \begin{tabular}{l|l}
11 & 3. \\
\end{tabular} & 3.2 & \begin{tabular}{l|l}
2 & 0 \\
\end{tabular} & \begin{tabular}{c|c|}
850 \\
\end{tabular} & & 0.18 - & 0.12 & \begin{tabular}{|l|l|}
0.23 \\
\end{tabular} & \begin{tabular}{|l|l|}
0.23 \\
\end{tabular} & \begin{tabular}{|l|}
0.09 \\
\end{tabular} & & & & & & \\
\hline C35 & 3.71 & 0.99 & 0.4 & & 1.1 & 4.8 & 2.6 & 13. & 63.2 & 20 & & & & 0.12 & & \begin{tabular}{|l|}
0.23 \\
\end{tabular} & \begin{tabular}{|l|l|}
0.09 \\
\end{tabular} & 0 & & & & & \\
\hline $\mathrm{C} 36$ & 4.10 & 1.42 & 0.8 & & 1. & \begin{tabular}{|l}
4.4 \\
\end{tabular} & 3.0 & $\begin{array}{ll}4 & 3 . \\
\end{array}$ & 73.6 & $\begin{array}{ll}3 & 0 \\
\end{array}$ & & & 0.60 & 0.54 & 0.54 & 0.54 & \begin{tabular}{|l|}
0.47 \\
\end{tabular} & \begin{tabular}{|l|l|l|} 
\\
\end{tabular} & & & & & \\
\hline $\begin{array}{l}37 \\
\end{array}$ & 4.20 & 1.06 & 0.4 & & 1.2 & $\begin{array}{ll}4 . \\
\end{array}$ & 42.6 & 83. & 3.2 & $\begin{array}{ll}9 & 0\end{array}$ & & & $\begin{array}{l}0.25 \\
\end{array}$ & 0.19 & 0.26 & \begin{tabular}{|l|l|}
0.26 \\
\end{tabular} & \begin{tabular}{|l|l|} 
\\
\end{tabular} .13 & \begin{tabular}{|l|l|l}
0.08 \\
\end{tabular} & $\begin{array}{l}.08 \\
0.36 \\
\end{array}$ & & & & \\
\hline C38 & 4.53 & 1.15 & 0.6 & \begin{tabular}{|l|l|}
0.8 \\
\end{tabular} & & 4.4 & 2 & \begin{tabular}{l|l}
9 & 3 \\
\end{tabular} & 93.5 & \begin{tabular}{l|l}
5 & 0 \\
\end{tabular} & & & & 0.59 & 0.72 & \begin{tabular}{|l|l|}
0.72 \\
\end{tabular} & 0.58 & \begin{tabular}{|l|l|l|}
0.5 & 0.5 \\
\end{tabular} & \begin{tabular}{l|l|l|l|}
50 & 0.54 \\
\end{tabular} & \begin{tabular}{c|c|c|}
54 & 0.48
\end{tabular} & & & \\
\hline $\begin{array}{l}\text { C39 } \\
\end{array}$ & 4.67 & 1.29 & 0.7 & 0.94 & 1.4 & 4. & 43.0 & 24. & 3.6 & $\begin{array}{ll}60 \\
60\end{array}$ & 320 & & 0.59 & 0.63 & 0.75 & \begin{tabular}{|l|l|l|}
0.75 \\
\end{tabular} & \begin{tabular}{|l|}
0.61 \\
\end{tabular} & \begin{tabular}{|l|l|l|}
0.53 \\
\end{tabular} & $\begin{array}{ll}53 & 0.45 \\
\end{array}$ & & $\begin{array}{ll}90.15 \\
\end{array}$ & & \\
\hline $\begin{array}{l}\mathrm{C} 40 \\
\end{array}$ & 4.40 & & 0.6 & \begin{tabular}{|l|l|}
1.07 \\
\end{tabular} & & & & & $\begin{array}{l}93.6 \\
9.6\end{array}$ & $\begin{array}{lll}4 & 0 \\
\end{array}$ & & & & & & & \begin{tabular}{|l|l|}
0.49 \\
\end{tabular} & \begin{tabular}{|l|l|l|} 
& 0.4 \\
\end{tabular} & \begin{tabular}{|l|l|l|l|l|} 
& 0.0
\end{tabular} & & 60.35 & 0.25 & \\
\hline
\end{tabular}

Tabel 4. Matriks Jarak Antaroutlet Wilayah Nusaniwe

\begin{tabular}{|c|c|c|c|c|c|c|c|c|c|c|c|c|c|c|c|c|c|c|c|c|c|c|}
\hline \multicolumn{23}{|c|}{ Data Jarak Tempuh (KM) } \\
\hline DariKe & PJM & & C48 & C49 & C50 & C51 & & 25 & & & & & & & C59 & C60 & C61 & C62 & C63 & $\begin{array}{lll}C 64 & \mathrm{C} \\
\mathrm{C}\end{array}$ & C65 & $\begin{array}{ll}C 66 & \mathrm{C} 67 \\
\end{array}$ \\
\hline PJM & & & & & & & & & & & & & & & & & & & & & & \\
\hline C47 & 5.20 & & & & & & & & & & & & & & & & & & & & & \\
\hline C48 & & 0.73 & & & & & & & & & & & & & & & & & & & & \\
\hline C49 & 5.60 & 0.28 & 0.46 & & & & & & & & & & & & & & & & & & & \\
\hline $\mathrm{C50}$ & 5.80 & 0.50 & 0.26 & 0.23 & & & & & & & & & & & & & & & & & & \\
\hline C51 & 5.82 & 0.52 & 0.25 & 0.24 & 0.02 & & & & & & & & & & & & & & & & & \\
\hline C52 & 5.82 & 0.52 & 0.25 & 0.24 & 0.02 & & & & & & & & & & & & & & & & & \\
\hline $\mathrm{C} 53$ & 6.33 & 1.02 & 0.32 & 0.75 & 0.58 & 0.5 & & & & & & & & & & & & & & & & \\
\hline C54 & 6.60 & 1.23 & 0.55 & 0.97 & 0.81 & 0.8 & & 300 & & & & & & & & & & & & & & \\
\hline $\mathrm{C} 55$ & 7.03 & 1.62 & 1.16 & 1.44 & 1.37 & 1.3. & & $\begin{array}{ll}360 \\
0\end{array}$ & & 0.73 & & & & & & & & & & & & \\
\hline $\mathrm{C56}$ & & 0.71 & 0.36 & 0.51 & 0.4 & 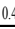 & & 460 & & 1.56 & 0.93 & & & & & & & & & & & \\
\hline $\mathrm{C} 57$ & 6.90 & 1.55 & 1.01 & 1.34 & 1.2 & 1.2. & & $\begin{array}{ll}23 & 0 \\
\end{array}$ & & 1.52 & 0.230 & 0.84 & & & & & & & & & & \\
\hline C58 & 6.91 & 1.70 & 1.15 & 1.49 & 1.3 & 1.3. & & 37 0 & & .64 & 0.230 & 0.99 & 0.15 & & & & & & & & & \\
\hline C59 & 7.70 & 1.95 & 1.30 & 1.71 & 1.5 & 1.5 & & 540 & & .75 & 0.661 & 1.25 & 0.51 & 0.43 & & & & & & & & \\
\hline C60 & 10 & 4.05 & 3.32 & 3.78 & 3.5 & 3.5 & & 553 & & 86 & 2.923 & 3.43 & 2.79 & 2.70 & 2.28 & & & & & & & \\
\hline $\mathrm{Cbl}$ & 6.40 & 1.15 & 0.66 & 0.95 & 0.86 & 0.8 & & 850. & & 37 & 0.500 & 0.44 & 0.40 & 0.55 & 0.85 & 3.10 & & & & & & \\
\hline $\mathrm{C} 62$ & 6.50 & 1.24 & 0.73 & 1.04 & 0.9 & 0.9 & & 840 & & 36 & 0.430 & 0.54 & 0.31 & 0.45 & 0.76 & 3.02 & 20.09 & & & & & \\
\hline C63 & 5.80 & 0.51 & 0.31 & 0.28 & 0.2 & 0.2 & & 880 & & 72 & 1.160 & 0.23 & 1.06 & 1.21 & 1.45 & \begin{tabular}{|l|l}
3.57 \\
\end{tabular} & 0.6 & 0.76 & & & & \\
\hline C64 & 5.70 & 0.38 & 0.74 & 0.43 & 0.6 & 0.6 & & 630 & & .10 & 1.330 & 0.53 & 1.31 & 1.45 & 1.76 & 3.96 & 60.9 & 1.01 & \begin{tabular}{|l|l|} 
\\
\end{tabular} & & & \\
\hline $\mathrm{C}_{65}$ & 5.73 & 0.40 & 0.76 & 0.45 & $\overline{0.6}$ & 0.6 & & & & .10 & 1.330 & & 1.31 & 1.44 & \begin{tabular}{|l}
1.76 \\
\end{tabular} & 3.97 & 70.92 & 1.01 & & 0.02 & & \\
\hline C66 & 5.30 & 0.77 & 1.25 & 0.93 & 1.1 & & & & & .53 & 1.570 & & 1.62 & 1.74 & 2.11 & 4.37 & 1.2 & 1.36 & 0.94 & 0.520 & 0.50 & \\
\hline $\mathrm{C} 67$ & & 0.65 & 1.25 & 0.87 & 1.00 & & & & & 61 & 1.75 & 1.05 & 1.77 & 1.90 & \begin{tabular}{|l|}
2.25 \\
\end{tabular} & 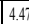 & 71.4 & 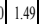 & 0.95 & \begin{tabular}{|l|l|l|}
0.52 \\
\end{tabular} & 0.51 & 0.25 \\
\hline
\end{tabular}

\section{Waktu Tempuh}

Waktu tempuh merupakan waktu yang dibutuhkan oleh kendaraan dalam proses pendistribusian barang. Kecepatan kendaraan yang digunakan adalah $40 \mathrm{~km} / \mathrm{jam}$. Rumus perhitungan waktu tempuh sebagai berikut:

Waktu tempuh $=\frac{d_{(i j)}}{v} \times 60$ menit

Keterangan: $d_{i j} \quad$ : Jarak tempuh $(\mathrm{km})$ $v:$ Kecepatan kendaraan $(\mathrm{km} / \mathrm{jam})$

Untuk melakukan kegiatan pengangkutan dan bongkar muat barang tersebut dibutuhkan waktu 0.15 menit tiap kartonnya sehingga perhitungan waktu total dapat diperoleh dengan menjumlahkan waktu tempuh dengan waktu bongkar muat tiap karton pada masing - masing outlet (Waktu tempuh total) 


\section{Model Matematik}

- Model matematik untuk wilayah Sirimau 1

Minimumkan $Z=\sum_{i=1}^{25} \sum_{j=1}^{25} C_{i j} X_{i j}$

dengan batasan,

$$
\begin{array}{ll}
\sum_{i=1}^{25} X_{i j}=1 & (j=1,2,3, \ldots .25) \\
\sum_{j=1}^{25} X_{i j}=1 & (i=1,2,3, \ldots .25) \\
X_{i j}=0 \text { atau } 1 &
\end{array}
$$

- Model matematik untuk wilayah Sirimau 2

Minimumkan $Z=\sum_{i=1}^{23} \sum_{j=1}^{23} C_{i j} X_{i j}$ dengan batasan,

$$
\begin{array}{ll}
\sum_{i=1}^{23} X_{i j}=1 & (j=1,2,3, \ldots . .23) \\
\sum_{j=1}^{23} X_{i j}=1 & (i=1,2,3, \ldots .23)
\end{array}
$$

$X_{i j}=0$ atau 1

- Model matematik untuk wilayah Nusaniwe

Minimumkan $Z=\sum_{i=1}^{22} \sum_{j=1}^{22} C_{i j} X_{i j}$

dengan batasan,

$$
\begin{array}{ll}
\sum_{i=1}^{22} X_{i j}=1 & (j=1,2,3, \ldots .22) \\
\sum_{j=1}^{22} X_{i j}=1 & (i=1,2,3, \ldots .22) \\
X_{i j}=0 \text { atau } 1 &
\end{array}
$$

\section{Algoritma dalam TSP}

Pemecahan kasus ini digunakan salah satu algoritma dalam TSP yaitu branch and bound. Algoritma ini menggunakan pohon pencarian (search tree), setiap simpul di pohon merupakan representasi dari sejumlah kemungkinan solusi dari TSP, serta algoritma two-way exchange improvement heuristic. Untuk penyelesaian dengan ketentuan jumlah $\mathrm{n}>10$ maka algoritma tidak dapat dikerjakan secara manual sehingga

\begin{tabular}{|c|c|c|c|c|}
\hline \multirow[b]{2}{*}{ Rute } & \multirow[b]{2}{*}{ Destinasi Outlet } & \multicolumn{3}{|c|}{ Jumlah } \\
\hline & & $\begin{array}{l}\text { Jarak } \\
(\mathrm{Km})\end{array}$ & Waktu & $\begin{array}{l}\text { Total } \\
\text { Waktu }\end{array}$ \\
\hline 1 & $\mathrm{PJM}-\mathrm{C1}-\mathrm{C} 2-\mathrm{C} 3-\mathrm{C} 4-\mathrm{C} 5-\mathrm{C} 6-\mathrm{C} 7-\mathrm{C} 8-\mathrm{PJM}$ & 8 & $12.02^{\prime}$ & $39.02^{2}$ \\
\hline 2 & $\mathrm{PJM}-\mathrm{C} 9-\mathrm{C} 10-\mathrm{C} 11-\mathrm{C} 12-\mathrm{C} 13-\mathrm{C} 16-\mathrm{C} 17-\mathrm{C} 18-\mathrm{C} 19-\mathrm{C} 20-\mathrm{C} 21-\mathrm{PJM}$ & 7.28 & $10.91^{\prime}$ & $46.16^{6}$ \\
\hline 3 & $\mathrm{PJM}-\mathrm{C} 22-\mathrm{C} 23-\mathrm{C} 24-\mathrm{C} 25-\mathrm{C} 26-\mathrm{PJM}$ & 12.19 & $18.28^{\prime}$ & $28.33^{\prime}$ \\
\hline 4 & $\begin{array}{l}\mathrm{PJM}-\mathrm{C} 14-\mathrm{C} 27-\mathrm{C} 28-\mathrm{C} 15-\mathrm{C} 29-\mathrm{C} 30-\mathrm{C} 31-\mathrm{C} 32-\mathrm{C} 33-\mathrm{C} 34-\mathrm{C} 35-\mathrm{C} 36 \\
-\mathrm{C} 37-\mathrm{C} 38-\mathrm{C} 39-\mathrm{C} 40-\mathrm{C} 41-\mathrm{PJM}\end{array}$ & 10.55 & 20.31 ' & $50.59^{\circ}$ \\
\hline 5 & PJM - C42-C46-C43-C44-PJM & 9.81 & $16.6^{\circ}$ & $33.31^{\circ}$ \\
\hline 6 & $\begin{array}{l}\text { PJM-C45-C56-C47-C48-C49-C50-C51-C52-C53-C54-C55-C57- } \\
\text { C58-C59-C60-C61-C62-C63-C64-C65-C66-C67-PJM }\end{array}$ & 22.93 & 34.39' & 87.1 ' \\
\hline & Total & 70.76 & $107.32^{\prime}$ & 284.51 \\
\hline
\end{tabular}
dilakukan dengan bantuan software WINQSB (Windows Quantitative System for Business).

\section{Rute Reguler/ Rute Awal PT. Paris Jaya Mandiri}

Rute regular merupakan rute yang biasanya dilalui petugas distribusi.
Tabel 5. Hasil Data Reguler

Penentuan Rute Menggunakan Algoritma Branch and Bound

Berdasarkan 3 kelompok wilayah distribusi dilakukan penyusunan rute baru berdasarkan letak outlet yang berdekatan. Kelompok wilayah 1 sebanyak 24 outlet dapat diperoleh 2 rute distribusi, kelompok wilayah sebanyak 22 outlet diperoleh 2 rute distribusi dan

\begin{tabular}{|c|c|c|c|c|c|}
\hline \multirow{2}{*}{$\begin{array}{l}\text { W } \\
\text { D }\end{array}$} & \multirow{2}{*}{ Rute } & \multirow{2}{*}{ Destinasi Outlet } & \multicolumn{3}{|c|}{ Jumlah } \\
\hline & & & $\begin{array}{l}\text { Jarak } \\
(\mathrm{Km})\end{array}$ & Waktu & $\begin{array}{l}\text { Total } \\
\text { Waktu }\end{array}$ \\
\hline \multirow{2}{*}{1} & 1 & $\mathrm{PJM}-\mathrm{C} 7-\mathrm{C} 6-\mathrm{C} 8-\mathrm{C} 2-\mathrm{Cl} 1-\mathrm{C} 5-\mathrm{C} 4-\mathrm{Cl} 13-\mathrm{Cl} 2-\mathrm{C} 21-\mathrm{C} 3-\mathrm{PJM}$ & 8.09 & $12.13^{\circ}$ & $46.03^{*}$ \\
\hline & 2 & $\begin{array}{l}\mathrm{PJM}-\mathrm{C} 9-\mathrm{C} 10-\mathrm{C} 11-\mathrm{C} 17-\mathrm{C} 19-\mathrm{C} 18-\mathrm{C} 20-\mathrm{C} 44-\mathrm{C} 43-\mathrm{C} 42-\mathrm{C} 46 \\
\mathrm{C} 45\end{array}$ & 947 & 142, & 592, \\
\hline \multirow{2}{*}{2} & 3 & $\mathrm{PJM}-\mathrm{C} 14-\mathrm{C} 15-\mathrm{C} 16-\mathrm{C} 22-\mathrm{C} 24-\mathrm{C} 25-\mathrm{C} 23-\mathrm{C} 26-\mathrm{PJM}$ & 1088 & $163^{\prime}$, & $3535^{\circ}$, \\
\hline & 4 & $\begin{array}{l}\text { PJM-C28-C29-C35-C34-C } 37-\mathrm{C} 38-\mathrm{C} 39-\mathrm{C} 40-\mathrm{C} 36-\mathrm{C} 33-\mathrm{C} 32- \\
\text { C31-C } 30-\mathrm{C} 27-\mathrm{PJM}\end{array}$ & 9.74 & $14.58^{\circ}$ & $43.08^{\circ}$ \\
\hline & 5 & PJM - C47 - C49-C50 - C52 - C51 - C48 - C53 - C54-C60- C59 - C58 - & 1987 & $298^{\circ}$ & $8305^{\circ}$, \\
\hline & & & 58.05 & 87.01 , $>$ > & 266.71 , \\
\hline
\end{tabular}
kelompok wilayah 3 sebanyak 21 outlet dapat diperoleh 1 rute distribusi. Dari hasil pengolahan data diperoleh 5 rute optimal dari 3 wilayah distribusi (WD) berdasarkan Branch and Bound sebagai berikut:

Tabel 6. Hasil Pengolahan Data Branch and Bound

Penentuan Rute Menggunakan Algoritma Two-Way Exchange Improvement Heuristic

Pada metode ini hasil yang diperoleh memiliki jarak dan waktu tempuh yang minimum dibandingkan dengan metode branch and bound. Selain itu dapat dilihat juga bahwa sesuai dengan lokasi hasil output rute ini juga mengalami kesamaan dengan lokasi pada rute 3, 4 dan 5 hasil branch and bound, tetapi pembeda pada hasil ini dengan metode branch and bound adalah pada urutan outlet yang dituju, Berikut ini merupakan tabel ringkasan pengolahan data rute terpendek dengan metode two-way exchange improvement heuristic. 
Tabel 7. Hasil Pengolahan Data two-way exchange improvement heuristic

\begin{tabular}{|c|c|c|c|c|}
\hline \multirow{2}{*}{ Rute } & \multirow{2}{*}{ Destinasi Outlet } & \multicolumn{3}{|c|}{ Jumlah } \\
\hline & & Jarak (Km) & Waktu & Total Waktu \\
\hline 1 & $\begin{array}{l}\text { PJM - C5 - C4 - C13-C12-C21-C3-C1- } \\
\text { C2 - C8 - C6 - C7 - PJM }\end{array}$ & 8.07 & $12.11^{\prime}$ & $46.01^{\prime}$ \\
\hline 2 & $\begin{array}{l}\mathrm{PJM}-\mathrm{C} 41-\mathrm{C} 45-46-\mathrm{C} 42-\mathrm{C} 43-\mathrm{C} 44-\mathrm{C} 20 \\
-\mathrm{C} 18-\mathrm{C} 19-\mathrm{C} 17-\mathrm{C} 10-\mathrm{C} 11-\mathrm{C} 9-\mathrm{PJM} \\
\end{array}$ & 9.47 & $14.2^{\prime}$ & $61.3^{3}$ \\
\hline 3 & $\begin{array}{l}\text { PJM - C24 - C25 - C23 - C26 - C22 - C16 - } \\
\text { C15 - C14-PJM }\end{array}$ & 10.87 & $16.29^{\prime}$ & 35.34 \\
\hline 4 & $\begin{array}{l}\text { PJM - C28 - C29 - C35- C34 - C37 - C38 - } \\
\text { C39 - C40 - C36 - C31 - C32 - C33 - C30 - } \\
\text { C27 - PJM }\end{array}$ & 9.72 & $14.57^{\prime}$ & $43.97^{\circ}$ \\
\hline 5 & $\begin{array}{l}\text { PJM-C47-C49-C50-C52-C51-C48- } \\
\text { C53-C54-C60-C59-C58-C55-C57- } \\
\text { 662-C61-C56-C63-C64-C65-C66- } \\
\text { C67-PJM }\end{array}$ & 19.83 & $29.75^{\prime}$ & $75.16^{\circ}$ \\
\hline & Total & 57.96 & 86.92 & 261.78 \\
\hline
\end{tabular}

\section{Analisa Perbandingan dengan Rute Reguler}

Hasil perbandingan pada tabel diatas menunjukan perubahan dari segi jarak akan mempengaruhi waktu tempuh dan total waktu setiap outlet. Antara rute regular dan rute hasil branch and bound dapat diperoleh selisih jarak tempuh sebesar $12.71 \mathrm{~km}$, selisih waktu tempuh sebesar 20.31 menit dan selisih total waktu adalah sebesar 22 menit. Sedangkan rute regular dengan rute hasil two way exchange improvement heuristic dapat diperoleh selisih jarak tempuh sebesar $12.8 \mathrm{~km}$, selisih waktu tempuh sebesar 20.4 menit dan selisih total waktu adalah sebesar 22.73 menit. Tabel 8 berikut menunjukan persentase penghematan hasil olahan dengan rute regular perusahaan

Tabel.8 Persentase Penghematan Hasil Olahan Data Dengan Rute Reguler Perusahaan

\begin{tabular}{|l|c|c|c|}
\hline \multicolumn{1}{|c|}{ Metode } & $\begin{array}{c}\text { Penghematan } \\
\text { Jarak }\end{array}$ & $\begin{array}{c}\text { Penghematan } \\
\text { Waktu }\end{array}$ & $\begin{array}{c}\text { Penghematan } \\
\text { Total Waktu }\end{array}$ \\
\hline Branch and Bound & $17.96 \%$ & $18.92 \%$ & $6.27 \%$ \\
\hline $\begin{array}{l}\text { Two Way Exchange } \\
\text { Improvement Heuristic }\end{array}$ & $18.09 \%$ & $19.01 \%$ & $7.99 \%$ \\
\hline
\end{tabular}

Dari hasil pengolahan data diatas menunjukan algoritma two way exchange improvement heuristic memberikan hasil rute yang paling optimal dibandingkan denga algoritma branch and bound, maupun algoritma cheapest insertion yang digunakan pada penelitian sebelumnya oleh Paillin dan Tupan 2018 yang di tunjukan pada gambar 3 berikut ini:

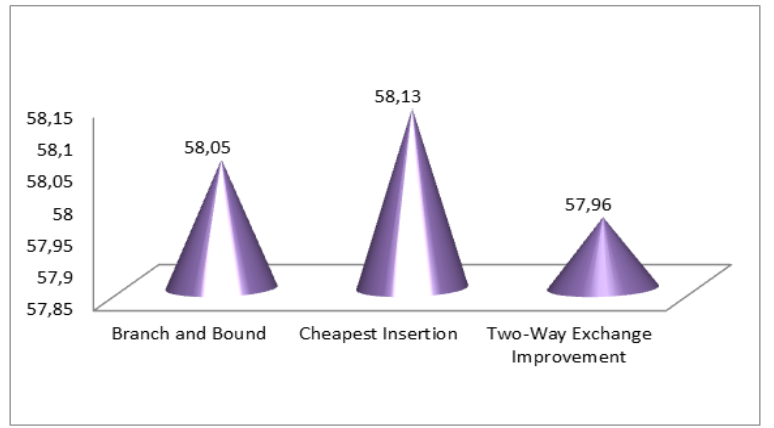

Gambar 3. Grafik Perbandingan Total Jarak Tempuh

Hasil persentase penghematan tersebut dapat memberikan keuntungan positif bagi perusahaan dimana terjadinya pengurangan jarak tempuh sebesar $18.09 \%$ yang bukan hanya mempengaruhi waktu tetapi juga berpengaruh pada penghematan biaya transportasi.

\section{KESIMPULAN}

Berdasarkan hasil pengolahan dan analisis data dari kedua metode yang digunakan maka dapat ditarik kesimpulan yaitu dipilih metode twoway exchange improvement heuristic yang memiliki output effisiensi rute tempuh baik dari segi jarak sebesar 18.09\%, waktu sebesar 19.01\%, dan waktu total $7.99 \%$. Persentase penghematan ini juga menunjukkan terjadi penghematan jarak sebesar $12.81 \mathrm{Km}$ dengan penghematan total waktu tempuh selama 22.73 menit dari rute awal perusahaan. Dari hasil metode metode Two-way Exchange Improvement Heuristic yang dipilih terdapat 5 rute optimal distribusi produk Nestle sebagai berikut:

- Rute 1 : PJM - Blitar- Nuryanti - Akbar Adin -Empat Jaya Toko - Mas Sri - Cahaya Fatan - Al Bagir - Herley - Mana Toko - Kios Julais - PJM. Total jarak tempuh adalah 8.07 $\mathrm{Km}$ dengan total waktu tempuh adalah 46.01 menit.

- Rute 2 : PJM - Anugrah Toko - Andi Kios Lily Toko - The Indah Toko- Ci Nona - Sovia Toko - Toko Ivan - Apotek Mannasuka - Fata Rahmat- Toko Mitra Jaya - Melissa 2 - Ko Han - Fandi - PJM. Total jarak tempuh adalah $9.47 \mathrm{Km}$ dengan total waktu tempuh adalah 61.3 menit

- Rute 3 : PJM - Kios 2 Putri - Balvis Kios Harmoni - Haikal - Teki Toko - Meter Toko Liana - Om Mon - PJM. Total jarak tempuh adalah $10.87 \mathrm{Km}$ dengan total waktu tempuh adalah 35.34 menit. 
- Rute 4 : PJM - Mustika Toko - Aping Toko Anda - Jerry Cell - Prison - Toko Biasa Berkat - Maluku Jaya Abadi - Surya Indah Toko - Jhon Coa - Rejeki Toko - Alan Sakura Toko - Mas No - PJM. Total jarak tempuh $9.72 \mathrm{Km}$ dengan total waktu tempuh 43.97 menit

- Rute 5 : PJM - Kios Anes - Safari TokoEmpi Toko - Kios Ema - Darren- Cempaka Toko - Damai Saparua - Spout Toko Natsepa Kios - Jaya Abadi Toko- Benteng Indah Toko - Mikael Toko - Sinar Mulia Toko - Beringin Baru - Linda Toko Annyong Tan - Kace Toko - Baru Toko Aliang Toko - Olive - Umar Toko - PJM. Total Jarak tempuh adalah $19.83 \mathrm{Km}$ dengan waktu tempuh 75.16 menit.

\section{DAFTAR PUSTAKA}

Davendra D. Travelling Salesman Problem Theory and Applications. Kroasia: Intech; 201

Fatmawati, Prihandono B, Noviani E, 2015. Penyelesaian Traveling Salesman Problem dengan Metode Tabu Search. Bimaster, Vol.4, No. 1, pp. 17-24

Hillier, F \& Lieberman, G.J (2001). Introduction to Operation Research. Seventh Edition. Mc Graw Hill . New York, USA

Lawler.E.L, Lenstra.J.K, Rinooy Kan. A.H.G, dan Shimoys. D.B., 1983, The Traveling Salesmen Problem (a Guided Tour of Combinatorial Optimization), John Wiley \& Sons, Chichester
Paillin, D. B dan Sosebeko I, 2017 Penentuan Rute Optimal Distribusi Produk Nestle dengan Metode TSP. Jurnal ARIKA, Vol 11 No. 1. Pp.31-40

Paillin, D. B dan Tupan J.M I, 2018. Pemecahan Traveling Salesman Problem Menggunakan Teknik Branch and Bound dan Cheapest Insertion Heuristic (Studi Kasus : PT. Paris Jaya Mandiri - Ambon). Industrial Engineering Conference (IDEC), Seminar Nasional "Peningkatan Daya Saing Industri Dan Pemberdayaan Tenaga Kerja Difabel Sebagai Tenaga Kerja Industri: Implementasi Alat Bantu Bagi Pekerja Difabel" Dan Workshop "Solve Industrial Engineering Problem Using Experimental Design Method"

Suyanto, 2010. Algoritma Optimasi (Deterministik dan Probabilistik). Yogyakarta: Penerbit Graha Ilmu; 